\title{
Use of Slow Sand Filtration to Complement Conventional Sewage Treatment Methods During Dry and Wet Seasons
}

\author{
Chebor Joel ${ }^{*}$, Lizzy A. Mwamburi, Ezekiel K. Kiprop, Becky N. Aloo \\ Department of Biological Sciences, University of Eldoret, Eldoret, Kenya \\ Email address: \\ jochebor@gmail.com (C. Joel), lizzymwamburi@hotmail.com (L. A. Mwamburi), kipropezekiel@gmail.com (E. K. Kiprop), \\ aloobecky@yahoo.com (B. N. Aloo) \\ ${ }^{*}$ Corresponding author
}

\section{To cite this article:}

Chebor Joel, Lizzy A. Mwamburi, Ezekiel K. Kiprop, Becky N. Aloo. Use of Slow Sand Filtration to Complement Conventional Sewage Treatment Methods During Dry and Wet Seasons. Frontiers in Environmental Microbiology. Vol. 2, No. 4, 2016, pp. 18-23.

doi: $10.11648 /$ j.fem.20160204.11

Received: August 16, 2016; Accepted: October 12, 2016; Published: November 8, 2016

\begin{abstract}
Conventional sewage treatment methods mostly do not treat wastewater adequately hence posing a huge problem to the survival of the aquatic life when released to the waterway. The objectives of the study were to evaluate the effect of seasonal variations on performance of both conventional sewage treatment and laboratory based $0.1 \mathrm{~mm}$ sand filter and to further improve the quality of the effluent from the treatment plant by subjecting the effluent to sand filtration for further treatment. Effluent from conventional sewage treatment plant was introduced into the filter. Pour plate method was used to determine total coliforms, BOD5 technique for Biological Oxygen Demand, COD digestion method for Chemical Oxygen Demand and gravimetric method for Total Suspended Solids. The parameters in this study were significantly $(<0.05)$ higher in the final effluent than in the filtrate during the two seasons. In addition, the parameters in the final effluent were significantly $(<0.05)$ lower during wet season compared to dry season. The two methods of wastewater treatment were efficient in treating the waste however, the conventional treatment plant was more efficient during wet season than dry season.
\end{abstract}

Keywords: Sand Filter, Wastewater, Seasonal Variations and Conventional Sewage Treatment Methods

\section{Introduction}

Rise in urbanization, population, economic developments and improved living conditions are the cause of increased generation of wastewater by the domestic, industrial and commercial sectors $[1,2,3]$. This increase has resulted to insufficient treatment of wastewater by the existing conventional sewage treatment methods. In Kenyan urban areas population growth has outpaced improvements in sanitation and wastewater infrastructure, making management of urban wastewater a tremendous challenge.

Wastewater is mostly disposed into natural waters by many countries. Huge amounts of organic matter and nutrients from raw sewage dumped to a weak hydrodynamic environment poses health and environmental problems from deterioration of water quality $[4,5,6,7]$. Over 5,200 water bodies in United States does not meet ambient water quality standards for their designated uses as a result of pathogens, while approximately 4,800 are impaired as a result of nutrients and partly due to failed onsite treatment and disposal systems [8].

In instances where wastewaters are treated, the treatment processes are often inadequate and the treated discharges are often still high in parameters such as BOD, nutrients and bacterial load. In fact, the prevalence of pathogenic microbes in treated wastewater has raised concerns about the capacities of existing treatment systems to efficiently remove these microbes [9]. Hence there is need to supplement the conventional methods of conventional sewage treatment by using slow sand filtration as one of the methods. Moreover, studies have shown that seasonal conditions appear to have a clear effect on performance efficiencies, emphasizing the need to determine the seasonal variations in performance efficiencies of existing and common waste water treatment systems [10].

Wastewater treatment using sand filters, waste stabilization or oxidation ponds and trickling filters singly or combined 
are widely used all over the world especially in tropical and subtropical countries $[11,12,13)$. However, very little work has been done so far on the seasonal variations associated with these wastewater treatment systems. The aim of the study was to evaluate the effect of seasonal variation on the efficiency of wastewater treatment by sand filters and conventional sewage treatment methods as well as to improve the effluent from treatment plant before releasing to the waterways. The parameters assessed included BOD, COD, TC and TSS. The seasonal assessment of presence or absence of TC was specially chosen because the presence of coliforms is usually assumed to indicate the potential presence of other faecal pathogens such as Salmonella spp., Shigella spp. or pathogenic strains of E. coli.

\section{Materials and Methods}

\subsection{Study Area, Design and Operation of Filters}

The study was carried out at Boundary Sewage Treatment Plant in Eldoret municipality, Uasin Gishu County, Kenya. It is one of the wastewater treatment plants within Eldoret municipality, located approximately ten kilometers from the town Central Business District (CBD). It treats both industrial and domestic wastewater. The treatment plant relies almost entirely on microbial treatment of waste; it has 1 screen, 2 primary oxidation ponds, 1 secondary oxidation pond, 1 sedimentation pond, 1 tertiary pond and 2 trickling filters. The study was carried out during the month of February to represent dry season and March to represent wet season. The final effluent from Boundary Sewage Treatment Plant was collected and analyzed for; biological oxygen demand, chemical oxygen demand, total coliforms and total suspended solids. Each parameter was tested in three replicates. Where analysis was not immediately possible, the samples were reserved by refrigeration at $4^{\circ} \mathrm{C}$.

After being analyzed, a sample of final effluent from Boundary Sewage Treatment Plant was passed through assembled slow sand filter of grain size $0.1 \mathrm{~mm}$ put on a 26 feet plastic PVC pipe. The effluent obtained from this filter were further collected and analyzed for BOD, COD, TSS and TC.

\subsection{Laboratory Analyses}

\section{Total coliform analysis}

Pour plate method was used to culture for total coliforms (TC)

Final effluent and filtrate samples collected were serially diluted then pour plate technique on Eosin Methylene Blue (EMB) was used and incubated at $37^{\circ} \mathrm{C}$ for 24 hours. Nucleated colonies with or without metallic sheen and pink in colour were counted with the aid of Gallenhamp colony counter as well as the colorless colonies. The populations of the viable colonies were obtained by the formula; number of counted colonies $\times$ dilution reciprocal [14]. This parameter was tested in three replicates for each collected sample for dry and wet seasons.

\subsection{Physicochemical Analyses}

\subsubsection{Determination of Biological Oxygen Demand (BOD)}

The BOD was obtained using the $\mathrm{BOD}_{5}$ trak technique procedure as described in the [15]. Nitrification inhibitor was first dispensed into a clean sterile empty BOD bottle. Collected sample of $500 \mathrm{ml}$ from final effluent from Boundary Sewage Treatment Plant and Filtrate from the filter were homogenised in a blender for 2 minutes. The $\mathrm{pH}$ of the two samples were adjusted to a range of 6.5-7.5 with either sulphuric acid or potassium hydroxide. Three hundred of the blended and adjusted $\mathrm{pH}$ samples were measured into the BOD bottle. A $3.8 \mathrm{~cm}$ magnetic stir bar was placed in each sample bottle then stopcock grease was applied to the seal lip of each bottle and to the cap of each seal cap. Then lithium hydroxide powder pillow was added to each seal cap, then the samples incubated at $20^{\circ} \mathrm{C}$ for five days. This parameter was tested in three replicates for each collected sample for dry and wet seasons.

\subsubsection{Determination of Chemical Oxygen Demand (COD)}

Chemical Oxygen Demand was determined using COD digestion procedure then the results read colorimetrically as described in [16]. A hundred millilitres of final effluent and filtrate samples were collected and homogenised in a blender for 2 minutes. Two millilitres of the homogenised samples were pipette into vials containing low range reagents. Two millilitres of deionised water were added to the vials containing low range reagents to produce a plank, then the vials were inverted gently several times and placed in a preheated COD reactor and left to heat for 2 hours at $150^{\circ} \mathrm{c}$. Thereafter, the vials were removed to cool to room temperature and finally programmed sphectrophotometer machine was used to read the results. This parameter was tested in three replicates for each collected sample for dry and wet seasons.

\subsubsection{Determination of Total Suspended Solids (TSS)}

The amount of TSS was obtained by using gravimetric method as described by [17]. Glass filter was dried by placing it in an oven with a temperature of $103^{\circ} \mathrm{c}$ for 60 minutes. After this duration the filter was removed and put in a desiccator to cool for 60 minutes and weight. A $100 \mathrm{ml}$ of the final effluent and filtrate samples were filtered through this glass filter and dried in the dessicator at $103^{\circ} \mathrm{c}$ for 60 minutes, removed and desiccated for another 60 minutes and weight. The weight of the sample was obtained by using the formula;

$$
\text { TSS mg/l }=(A-B) \times 100 \div \text { sample volume }
$$

Where $\mathrm{A}=$ weight of the filter plus dried residue in $\mathrm{mg}$ $\mathrm{B}=$ weight of the filter in $\mathrm{mg}$

This parameter was tested in three replicates for each collected sample for dry and wet seasons.

\subsection{Statistical Analysis}

$\mathrm{T}$ - Test was used to analyze the data and graphs used to present the results. 


\section{Results}

One sample $\mathrm{t}$ test was used to analyze the significance difference between the parameters tested in the final effluent during dry and wet seasons as well as the significant differences between the final effluent and the $0.1 \mathrm{~mm}$ filtrate during the two seasons. Bar graphs were used to support this $\mathrm{t}$ - test analysis.

Table 1. One sample t test showing the comparison of the parameters in the final effluent from Boundary Sewage Treatment Plant between dry and wet seasons.

\begin{tabular}{|c|c|c|c|c|c|c|c|c|}
\hline \multirow{2}{*}{ Parameter } & \multirow{2}{*}{$\begin{array}{l}\text { Mean during } \\
\text { dry season }\end{array}$} & \multirow{2}{*}{$\begin{array}{l}\text { Mean during } \\
\text { wet season }\end{array}$} & \multirow{2}{*}{$\mathbf{T}$} & \multirow{2}{*}{ Df } & \multirow{2}{*}{ Sig. (2-tailed) } & \multirow{2}{*}{$\begin{array}{l}\text { Mean } \\
\text { difference }\end{array}$} & \multicolumn{2}{|c|}{$95 \%$ confidence interval of the difference } \\
\hline & & & & & & & Lower & Upper \\
\hline BOD (mg/l) & 82.67 & 28 & 12.615 & 2 & 0.006 & 54.66667 & 36.0218 & 73.3115 \\
\hline $\mathrm{COD}(\mathrm{mg} / \mathrm{l})$ & 169 & 76.67 & 277.000 & 2 & 0.000 & 92.33333 & 93.7676 & 90.8991 \\
\hline TSS (mg/l) & 90 & 62 & 28.000 & 2 & 0.001 & 28.00000 & 32.3027 & 23.6973 \\
\hline TC (cfu / $100 \mathrm{ml})$ & 4500 & 1600 & 50.229 & 2 & 0.000 & 2900.00000 & 2651.5862 & 3148.4138 \\
\hline
\end{tabular}

All the parameters (BOD, COD, TSS and TC were significantly $(\mathrm{p}=<0.05)$ higher in the final effluent during dry than wet season. The amount of BOD, COD, TSS and TC were $82.67 \mathrm{mg} / 1,169 \mathrm{mg} / 1,90 \mathrm{mg} / \mathrm{l}$ and $1600 \mathrm{cfu} / 100 \mathrm{ml} \mathrm{respectively} \mathrm{during}$ dry season compared to $28 \mathrm{mg} / 1,76.67 \mathrm{mg} / \mathrm{l}, 62 \mathrm{mg} / \mathrm{l}$ and $1600 \mathrm{cfu} / 100 \mathrm{ml}$ during wet season.

Table 2. Comparison of final effluent from boundary sewage treatment plant with the effluent from filter $0.1 \mathrm{~mm}$ during dry season.

\begin{tabular}{|c|c|c|c|c|c|}
\hline Parameter & Mean of final effluent & Mean of $0.1 \mathrm{~mm}$ filtrate & Mean difference & Std. error mean & Sig. $(2-$ tailed $)$ \\
\hline BOD (mg/l) & 82.67 & 33.33 & 49.33333 & 4.63081 & .009 \\
\hline COD (mg/l) & 169 & 74.33 & 94.66667 & 5.17472 & .003 \\
\hline $\mathrm{TSS}(\mathrm{mg} / \mathrm{l})$ & 90 & 81.67 & 8.33333 & .66667 & .006 \\
\hline $\mathrm{TC}(\mathrm{cfu} / 100 \mathrm{ml})$ & 4500 & 960 & 3540.00000 & 52.91503 & .000 \\
\hline
\end{tabular}

The parameters (BOD, COD, TSS and TC were significantly $(p<0.05)$ higher in the final effluent than in the filtrate during dry season. The amount of BOD in the final effluent was $82.67 \mathrm{mg} / \mathrm{l}$ compared to $33.33 \mathrm{mg} / \mathrm{l}$ obtained in the filtrate, COD in the final effluent was $169 \mathrm{mg} / \mathrm{l}$ higher than those gotten in the filtrate of $74.33 \mathrm{mg} / \mathrm{l}$, TSS in the final effluent during dry season was $90 \mathrm{mg} / \mathrm{l}$ higher than 81.67 of filtrate and TC of $4500 \mathrm{cfu} / 100 \mathrm{ml}$ was higher compared to $960 \mathrm{cfu} / 100 \mathrm{ml}$ of the filtrate.

Table 3. Comparison of final effluent with filtrate from filter $0.1 \mathrm{~mm}$ during wet season.

\begin{tabular}{llllll}
\hline Parameters & Mean of final effluent & Mean of filtrate & Mean difference & Std. error mean & Sig. (2 - tailed) \\
\hline BOD $(\mathrm{mg} / \mathrm{l})$ & 28 & 22 & 6.00000 & 1.15470 & 0.035 \\
COD $(\mathrm{mg} / \mathrm{l})$ & 76.67 & 68.67 & 8.00000 & 0.57735 & 0.005 \\
TSS $(\mathrm{mg} / \mathrm{l})$ & 62 & 55 & 7.00000 & 1.00000 & 7.000 \\
TC & 1600 & 706.67 & 893.33333 & 3.33333 & 0.000 \\
\hline
\end{tabular}

All parameters were significantly $(\mathrm{p}<0.05)$ lower in the filtrate compared to the final effluent during wet season. The amount obtained for BOD in the filtrate was $22 \mathrm{mg} / \mathrm{l}$ compared to those obtained in the final effluent of $28 \mathrm{mg} / \mathrm{l}$, the amount of COD in the filtrate was $68.67 \mathrm{mg} / \mathrm{l}$ which is lower than COD of $76.67 \mathrm{mg} / 1$ in the final effluent, TSS in the filtrate was $55 \mathrm{mg} / \mathrm{l}$ compared to $62 \mathrm{mg} / \mathrm{l}$ in the final effluent, $706.67 \mathrm{cfu} / 100 \mathrm{ml}$ was found in the filtrate compared to $1600 \mathrm{cfu} / 100 \mathrm{ml}$ in the final effluent.

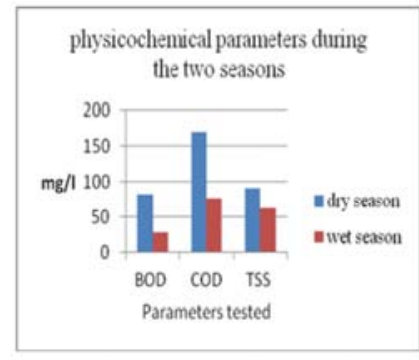

1a

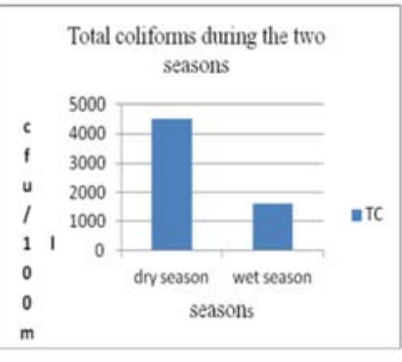

$1 \mathrm{~b}$
Fig. 1. Comparative bar graph showing physicochemical parameters (BOD $C O D$ and TSS) and total coliforms in the final effluent from Boundary
Sewage Treatment Plant during dry and wet seasons. The graph shows that the parameters registered higher figures during dry season than wet season.

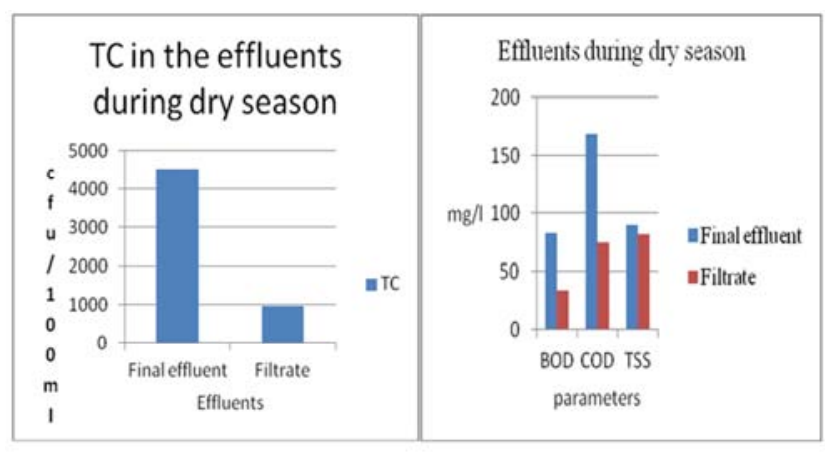

$2 \mathrm{a}$

$2 \mathrm{~b}$

Fig. 2. Bar graphs showing the comparison of the amounts of the parameters in the final effluent from Boundary Sewage Treatment Plant and the filtrate from the $0.1 \mathrm{~mm}$ sand filter during dry season. Biological oxygen demand, chemical oxygen demand, total suspended solids and total coliforms in the final effluent sample were higher than in the $0.1 \mathrm{~mm}$ filtrate. 


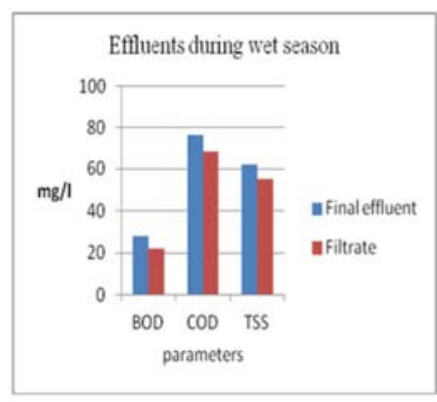

3a

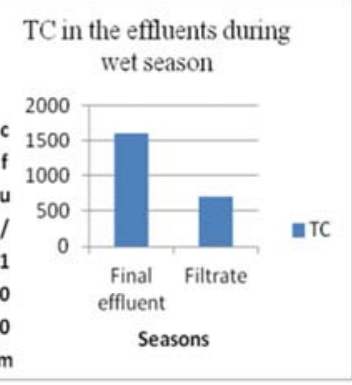

$3 \mathrm{~b}$
Fig. 3. Bar graphs showing the comparison of the amounts of the parameters in the final effluent from Boundary Sewage Treatment Plant and the filtrate from the $0.1 \mathrm{~mm}$ sand filter during wet season. Both the coliforms and the physicochemical parameters were lower in the filtrate than in the finale effluent from the conventional sewage treatment Plant.

\section{Discussion}

The analyzed data and the graphs showed the seasonal effect on the performance of the two wastewater treatment systems studied; the conventional sewage treatment methods and the $0.1 \mathrm{~mm}$ slow sand filter. In addition the filter significantly improved the quality of final effluent from the treatment plant before being released into the Sosiani river.

The massive reduction of TC observed in this study during wet season than in dry season could be attributed to a number of factors that together eliminate these and other bacteria in wastewater treatment plants. [18] Suggested that the prevailing environmental conditions are among the controlling factors on the abundance and survival of bacteria in the environment. The temperature changes in the wet season may have affected the survival of the enteric bacteria, TC included during this period of study. [19] Found that temperature and seasonal conditions affect a number of both physical and biological activities within the treatment system and therefore the treatment efficiency. Efficient removal of bacteria in maturation oxidation ponds depend on environmental conditions and are therefore variable seasonally [20]. (21) Demonstrated that bacteria of the coliform group tend to have higher die-off rates during the cold season as opposed to the dry season and indicated that at temperatures above $21^{\circ} \mathrm{C}$ which is the case in dry seasons when temperatures rise above $30^{\circ} \mathrm{C}$, coliform die off rates decrease due to anaerobic conditions that arise during this season.

The current study findings corroborate that of [22] who reported higher bacterial densities in dry season than wet season. Additionally, in combined sewer system, like the case of Boundary Sewage Treatment Plant, wastewater quality is subject to dilution by rain water. This study findings corroborates with those of [23] who observed low bacterial counts in the effluent of Akosombo waste stabilization ponds, Ghana and attributed it to rain dilution and further corroborates those of [24] Who also experienced lower pathogenic bacteria during wet season than dry in the final effluent of Dandora sewage Treatment Plant, Nairobi, Kenya. They also attributed this disparity to dilution effect due to rainfall during rainy season.

The conventional sewage treatment systems is a system commonly used in most municipal sewage treatment plants, The significant difference that exists in the physicochemical parameters during dry and wet season and registration of lower figures during wet season could be attributed to various factors; Biological oxygen demand and chemical oxygen demand were lower during wet season than dry after the wastewater been treated by the combination of oxidation ponds and trickling filters. This could be adduced to dilution effect by rainfall during wet season. The rainfall by directly falling on the open wastewater treatment system could have led to increase in volume of water in the wastewater treatment system thereby leading to increased rate of dispersion of organic matter. These findings are similar to those of [25] who attributed their relative higher values of BOD and COD in dry season than wet to dilution of the stream by rain. [26] In his study on seasonal variation on greywater also concluded that the fewer amounts of COD in rainy season than winter and summer was partly due to less dilution occurred in greywater during January. Similarly to studies by [27], they demonstrated that the design parameters such as BOD in oxidation ponds attain maximum values in the hot season and minimum values in the wet/cold season. This treatment system one tend to be more efficient during wet season than during the dry season.

The significant reduction of TSS during wet season than dry could be as a result of the high rates of evaporation that occur during the dry season leading to increased concentration of solids that are suspended in less volumes of water. Since evaporation rates are bound to be lower during the wet season, more volumes of wastewater are likely to carry less amounts of suspended solids. These findings are consistent to those of [28] who found that TSS means were higher during dry season than wet and attributed these findings to dilution effect of rainfall

The same trend was observed for reduction of the physicochemical parameters in $0.1 \mathrm{~mm}$ sand filtered effluents with lower means being recorded for those parameters in effluents during the wet season.

The lower means of the parameters from the sand filtered effluents during wet season than dry together with their significant difference is attributed to lower means of these parameters in the effluent from the conventional sewage treatment system of treatment during wet season than dry season.

The $0.1 \mathrm{~mm}$ sand filter further treated the wastewater effluents from the combination of oxidation ponds and trickling filters. This observation can be explained by the fact that in the wet season, even the unfiltered effluents contained lower levels of these parameters and thereby when filtered, the effluents would still contain lower values of these effluents during the wet season. The efficiency of the sand filters in improving the influent from the treatment plant across the two seasons could be attributed to the various treatment mechanisms in the sand filters. Several mechanisms for the removal of particles, microorganisms and 
organic matter exist in slow sand filters have been documented. As water percolates through the sand, organic material and microorganism are removed by both mechanical (absorption, diffusion, screening and sedimentation) and biological processes (predation, natural death and metabolic breakdown [29].

It was evident from these results that the sand filters were capable of treating wastewater effluents from wastewater treatment system one to a better quality than could be achieved by the conventional sewage treatment method. The sand filters are efficient and can be employed for tertiary treatment of sewage effluents before disposal into water ways. Although the reduction of means of parameters studied was lower in conventional sewage treatment method, the slow sand filter also treated the wastewater effluents further well during both seasons.

\section{Conclusions}

From the results of this study, it was concluded that Boundary Sewage Treatment Plant was more efficient during wet season than dry season, the study could attribute this to dilution effect by rain during wet season. The $0.1 \mathrm{~mm}$ filter employed by this study treated further the treated final effluent from the treatment plant during both dry and wet season and reduced the amount of the parameters under study (BOD, COD, TSS AND TC). This positive contribution of $0.1 . \mathrm{mm}$ filter in treating wastewater can be employed in large scale in conventional sewage treatment plant to further polish the wastewater before being released into the waterways so that aquatic life could no longer be in danger.

\section{Acknowledgements}

Thanks to the Eldoret water and sanitation company for granting us permission to carry out the study at their treatment plant, and also by giving us their materials, reagents and equipments to be used in this study.

\section{References}

[1] Lazarova, V., and Bahri, A. 2005. Water reuse for irrigation: agriculture, landscape turf grass, CRS PRESS, BOC A ration, FL, 2005.

[2] Asano T., Burton F. L., Leverenz, H., Tsuchihashi, R. and Tchbanoglous, G. Water reuse: issues, technologies and applications. New York: McGraw Hill, 2007.

[3] Qadir, M., Wicheins, D., Raschid - Sally, L., McCornick, P. G., Drechsel, P., Bahri, A., and Minhas, P.S. 2009. The challenges of wastewater irrigation in developing countries. Agriculture water management (in press), 2009.

[4] Ribiero, C.H., and Araujo, M. Mathematical modeling as a management tool for water quality. Control of the tropical bebellbe estuary, NE Brazil. Hydrobiologia. 475 (1): 229-237, 2002.

[5] Crimio, G., Puleio, M. C., and Toscano, G. Quality assessment of freshwater and coastal seawater in the Ionian area of N. E. Sicily, Italy. Environ. Monit. Assess, 77(1): 61-80, 2002.

[6] Rajagopalan, V. 2005. Sewage pollution. Central Pollution Control Board, Ministry of Environment and Forests. Retrieved from: http://cpcbenvis.nic.in/newsletter//default newsletter.htm (Accessed date: March 10, 2010, 2005

[7] $\mathrm{Al}-\mathrm{Dahmi}, \mathrm{H}$. Raw sewage and marine pollution information source. National scientific and technical information centre Kuwait institute for scientific research. Retrieved from: http://.docstoc.com/docs/downloaddoc.aspx?doc$\mathrm{id}=22862709$. (Accessed date: February 1, 2010), 2009

[8] USEPA. EPA guidelines for management of onsite decentralized wastewater systems. USEPA Report, $832 \mathrm{~F}-00$ $-012,2000$.

[9] Maunula, L., Klemol, P., Kauppinen, A., Soderberg, K., Ngujen, T., Pitkänen, T., Kaijalainen, S., Simonen, M. L., Miettinen, I.T., Lappalainen, M., Laine, J., Vuento, R., Kuusi, M., and Roivainen. Enteric viruses in a large waterborne outbreak of acute gastroenteritis in Finland, Food Environ. Virol. 1: 31-36, 2009.

[10] Mahgoub, S., Abdelbasit, H., Abdelfattah, H., and Hamed, S. Monitoring phenol degrading Candida and bacterial pathogens in sewage treatment plant, Desalin. Water Treat. 1-8, 2014.

[11] . Khan, M. A., Shaukat, S. S., and Khan, M. A. 2008. Economic benefits from irrigation of maize with treated effluent of waste stabilization pond. Pak. J. Bot. 40(3): 1091$1098,2008$.

[12] Khan, M. A., Shaukat, S. S., and Khan, M. A. Growth, yield and nutrient content of sunflower (Helianthus annus L.) using treated wastewater from waste stabilization ponds. Pak. J. Bot. 41(3): 1391-1399, 2009.

[13] Alcalde, L, Oron, G, Gillerman, L, Salgot, M., and Manor, Y. Removal of faecal coliforms somatic coliphages and Fspecific bacteriophages in a stabilization pond and reservoir system in arid regions. Wat. Sci. Tech. 3: 177-184, 2003.

[14] Madigan, M. T., Martinko, J. M., Dunlap, P. V., and Clark, D. Brock Biology of Microorganisms. Pearson international edition twelfth edition. Pearson Benjamin Cummings 1301 Sansome street San Francisco, Ca 9411, 2009.

[15] Hach. Sphectrophotometer DR/2400 procedure. Hach Company U.S.A, 2002.

[16] Hach. BOD trak instrument manual cat, No $26197-18$. Hach company U.S.A, 1995-1998.

[17] Greenberg, A. E, Lenore, S.C and Eaton, A.D. (Ed) 1995.Standard methods for the examination of water and wastewater $\left(19^{\text {th }}\right.$ ed). Washington, DC 2005 pp 2.55, 2.56, 2002.

[18] Groth, I and Saiz-Jimenez, C. 1999. Actinomycetes in hypogean environments. Geomicrobiol. J. 16: 1-8, 1999.

[19] Werker, A. G., Dougherty., J. M., McHenry J. L., and Van Loon W. A. 2002. Treatment variability for wetland wastewater treatment design in cold climates. Ecol. Eng. 19: $1-11,2012$.

[20] Troussellier, M., Legendre, P., and Baleux, B. Modeling the evolution of bacterial densities in a eutrophic ecosystem (sewage lagoons). Microb Ecol. 12: 355-379, 1986. 
[21] Marais, G.V.R. 1974. Faecal bacteria kinetics in waste stabilization ponds. JEED ASCE, 100 (EE1): 119-139, 1974.

[22] Wemedo, S. A., Obire, O., Akani, N. P. Bacterial Population of an Oilfield Wastewater in Nigeria. Asian J. Biol. Sc. 5: 46-51, 2012.

[23] Hodgson, A. Performance of the Akosombo waste stabilization ponds in Ghana. Ghana J.Sci.47: 35-44, 2007

[24] . Musyoki, A. M., Mbaruk, A. S., Mbithi, J.N., and Maingi, J.M. Diurnal and seasonal variations of pathogenic bacteria in Dandora sewage treatment plant, Nairobi Kenya. JREST (ISSN: 2315-5698) 2 (2): 36-41, 2013.

[25] Kayima, J., Kyakula. M., Komakech, W., and Echimu, S.P. A study of the degree of pollution in Nakivubo channel,
Kampala, Uganda. J. Appl. Sci. Environ. Manage. 12 (2): 9398, 2008.

[26] Maltreyee, M.T. Seasonal Variation in greywater quality for real life system. IJRET 03: 768-770, 2014.

[27] Mara, D. D., and Pearson, H. W. Artificial fresh water environments: waste stabilization ponds. Biotechnology 8 (ed. W. schoernbon): 177-206, 1998.

[28] Monney, I., Odai, S. N., Buamah, R., Awuah, E., and Nyenje, P.M. Environmental impacts of wastewater from urban slums: Case study - old Fadama, Accra. International Journal of development and sustainability. vol. 2 (2): 711-728. 2013.

[29] Logsdon, G. Slow Sand Filtration for small Water Systems. In: J Environ Engineering and Sci. 1: 339-348, 2002. 